\title{
JOHN DALTON, F.R.S., D.C.L., LL.D., CAPTAIN JOSEPH HUDDART, F.R.S., AND THE HARRIS FAMILY* HISTORICAL NOTES ON CONGENITAL COLOUR BLINDNESS
}

\author{
BY \\ J. W. CRERAR AND J. A. ROSS \\ Maryport Bridge of Allan
}

These three names, all of Cumbrians, are closely associated in the early history of congenital colour blindness. John Dalton (1798) made careful and detailed observations on his own and other cases which are universally recognized, but he was not, as is commonly and erroneously believed, the first to draw attention to this condition. The early use of the term "Daltonism " no doubt fostered such a belief, so that the name of Joseph Huddart (1777) is almost forgotten, although it was he who first drew attention to " supernatural vision ", as it was then called, and was the first to use coloured objects to test those affected and to record their reactions. He also noted the occurrence of colour blindness in male members of the same family who were Quakers " among whom a general uniformity of colours is known to prevail". Our quest originated in a reference, in a brief biography of Joseph Huddart, to a letter† giving " An Account of Persons who could not distinguish Colours", written by him to the Rev. Joseph Priestley, F.R.S. Priestley read this letter to the Royal Society on February 13, 1777, at which time Dalton was only in his 11th year.

Joseph Huddart (1741-1816), born in Allonby, a village near Maryport in Cumberland, had a remarkable career. The only son of a fisherman, he followed his father's occupation until 1768 when he had a brig built at Maryport in which he traded with Ireland and North America. He entered the service of the Honourable East India Company in 1773 as fourth officer and on a voyage in that year surveyed the west coast of Sumatra. He returned home in 1775, and in 1777 surveyed the St. George's channel. In 1778 he rejoined the company as chief officer, and later captain, of the Royal Admiral.

Retiring from the sea in 1788, he devoted himself to hydrographic and survey work. on the west coast of Scotland and numerous harbours and docks. He was elected an Elder Brother of Trinity House and F.R.S. in 1791. Throughout his life he had been greatly interested in optical problems as evidenced by the letter to Priestley mentioned above, and by a paper he read to the Royal Society on "Horizontal Refraction" in 1796.

He died in London in 1816. A monument to his memory was erected by his son, Sir William Huddart, in Christ Church, Allonby, to whose first

\footnotetext{
* Received for publication December 1, 1952.
}

+ Now preserved in the British Museum. 
vicar, the Rev. Thomas Wilson, the young Joseph Huddart had been indebted for his education.

Huddart's was the first reliable record of inability to distinguish colours. In the case recorded by Turberville of Salisbury (1684), a young girl is said to have been unable to distinguish colours except black and white, but as she is also said to have been able to read in the greatest darkness and to have seen terrifying bulls and bears invisible to others, it seems evident that she suffered in fact from some cerebral or mental disorder. No objective evidence is given, only the statements of the girl herself.

In his letter to Priestley, Huddart tells of his 10 years' acquaintance with Harris [Thomas] " by trade a shoemaker at Maryport", and of his frequent conversations with him,

an intelligent man and very desirous of understanding the nature of light and colour, for which he had attended a course of lectures on natural philosophy ... I believe he could do no more than guess the name of any colour; yet he could distinguish white from black. Dark colours in general he often mistook for black.

He had two brothers [actually three] in the same circumstances as to sight; and two other brothers and sisters who, as well as their parents, had nothing of this defect.

One of these brothers [Jonathan], a master mariner, Huddart met in Dublin in December, 1776, and tested carefully with striped ribbons, " not having a prism by me": of four black stripes of exactly the same shade he declared three to be brown and only one black, the light green he called yellow, a reddish tinge he called a sort of blue.

But he was most of all deceived by the orange colour; of this he spoke very confidently, saying, "This is the colour of grass; this is green".

This is the first recorded use of coloured objects for testing colour vision ; a method followed and extended by John Dalton in his own case about 13 years later (1790).

Huddart's communication attracted little attention, only the two following references being made to it during the 17 years that elapsed before Dalton's communication:

(i) In 1778 the Rev. Michael Lort wrote to the Royal Society describing the case of Mr. J. Scott. This letter contains the first reference to colour-blindness in a female-a member of the Scott family (Lort, 1778).

(ii) In 1779 the Abbé Rozier translated Huddart's paper into French and recorded the case of Collardeau, a painter (Rozier, 1779.)

John Dalton (1760-1844), in his historic paper "Extraordinary Facts relating to the Vision of Colours, with Observations ", read on October 31, 1784 , before the Literary and Philosophical Society of Manchester, mentioned that he had read and re-read the account of the case of Mr. Harris of Maryport in Cumberland in the Philosophical Transactions (Huddart, 1777) and mentioned Rozier's translation. Having an acquaintance in Maryport 
(Joseph Dickinson) he had asked him to propose some queries to the surviving colour-blind Harris brother [actually two brothers, Joseph and John]. This important paper is so well known that it is unnecessary to refer to it in detail. In his correspondence (1793-1794) with Dalton, Joseph Dickinson identified by name the four colour-blind members of the Harris family: II, 1 and 8, Thomas and Jonathan (the Master Mariner), both long since dead, and II, 2 and 7, Joseph and John, the two living brothers.

Incidentally it may be mentioned that Dickinson himself had married Mary, the only daughter of Thomas Harris, and that his only son Isaac was colour-blind.

Two curious pieces of information may be of interest. Dalton had surmised that the cause of his odd vision might be " some colouration of the humours of his eyes, probably some modification of blue in the vitreous", and he desired that his eyes should be examined after his death. Dr. John Ransome removed them and found that " the aqueous humour, the vitreous and its hyaloid membrane were perfectly colourless". One of these dissected eyes is still to be seen at Dalton Hall, Manchester.

Under the great council table in Manchester Town Hall, where it had been used as a footstool, a bust of John Dalton was discovered by a friend and by him cleaned and restored. It was sent to the Chemistry Department at Cambridge, and on arrival consigned to a storeroom. Many years later this bust was recognized by Professor A. R. Todd and given its present place of honour in his Senior Research Laboratory in Pembroke Street, Cambridge.

\section{The Harris Genealogical Table}

Dr. Julia Bell gives a Table compiled from Dalton's statements and the Records of the Society of Friends, and expresses doubt as to II, 7, surmising that he was colour-blind (Bell, 1926). Her table and ours are set out in the Figure.

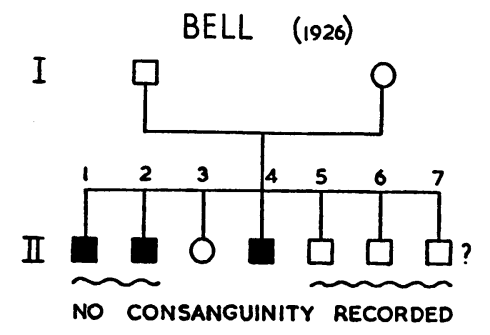

FIGURE. - The Harris pedigree as set out by Bell (1926) and as compiled in recent investigations.

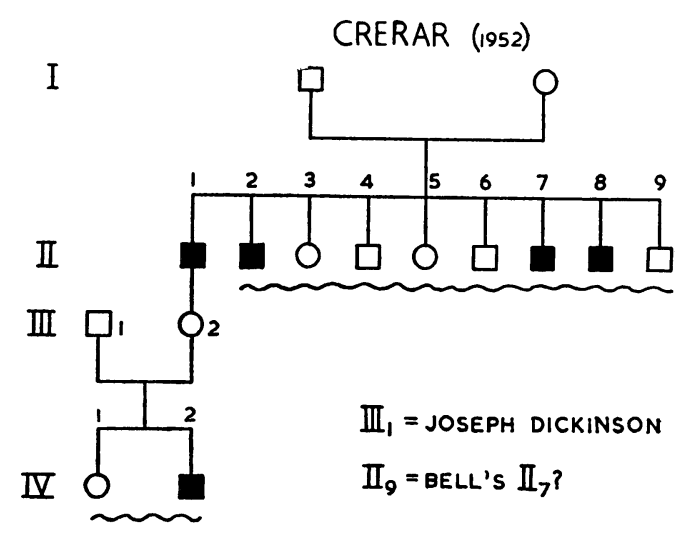


One of us (J.W.C.), who for many years practised in Maryport, had the opportune good fortune to have access to the Netherhall (Maryport) Estate Records ; to have certified copies made of entries in the Friends' Registers at Wigton, Cumberland ; and especially, thanks to a member of the family, to peruse the carefully detailed Harris papers which give the irrefragable pedigree of the family of William and Hannah Harris, and incidentally of the maternal descent of the immortal Joseph, Lord Lister.

Anthony Harris (1755-1795) the youngest of the family (II, 9) was a master mariner and was drowned at sea ; he married Isabella Bull of Dublin, and they had eight children. The fifth, Elizabeth, was the grandmother of the late Mrs. George Cadbury, D.B.E. The sixth, Isabella, born in Maryport in 1792, married Joseph Jackson Lister in 1818, and the fifth of their eight children was Joseph, Lord Lister (1827-1912). She was the grandmother of Sir Rickman Godlee, P.R.C.S. - the biographer of his uncle Joseph-and of Sir William Lister, K.C.V.O., the oculist. She is beautifully portrayed in Godlee's biography.

Anthony Harris had normal vision. Had he been colour-blind and had Isabella transmitted the defect to her male descendants, would Lord Lister, Sir Rickman Godlee, and Sir William Lister have become surgeons ? It seems impossible that an ophthalmologist could be colour-blind, but some 30 years ago a general surgeon of the highest standing among his fellows was found by one of us (J.A.R.) to be as colour-blind as was John Dalton.

\section{Summary}

The particular contributions of John Dalton, Joseph Huddart, and the Harris family to the subject of congenital colour blindness are examined. While the outstanding importance of Dalton's work is not overlooked or minimized, Huddart's claim to priority is confirmed and fortified.

The descent of Lord Lister, Sir Rickman Godlee, and Sir William Lister from Isabella Harris is indicated.

Acknowledgments are due first and foremost to Dr. Julia Bell and her encyclopaedic work-a storehouse of accurate and detailed information; to the member of the Harris family who placed the Harris papers at our disposal; to Mr. Robert Ritson, barrister-at-law, London, for the transcripts of Huddart's and of Dalton's communications; and to the Librarians of the B.M.A., of Tullie House, Carlisle, and of the Manchester City Library for their invaluable assistance.

\section{REFERENCES}

BeLl, Julia (1926). Eugenics Laboratory Memoirs No. 23, “ The Treasury of Human Inheritance ", vol. 2, pt. 2, " Colour Blindness ", figs 401 and 570; pp. 224 and 257. University Press, Cambridge.

Dalton, J. (1798). Memoirs of the Literary and Philosophical Society of Manchester, vol. 5, pt. 1, p. 28. Cadell and Davies, London.

Dalton File, Manchester City Library.

Huddart, J. (1777). Phil. Trans. roy. Soc., 67, pt. 1, p. 260.

LORT, M. (1778). Ibid., 68, pt. 2, p. 611.

ROZIER, L'ABBÉ (1779)." "Observations sur la physique, sur l'histoire naturelle et sur les arts", vol. 13, p. 86. Paris.

SorsBy, A. (1951). "Genetics in Ophthalmology", p. 36. Butterworth, London. 